OPEN ACCESS

Edited by:

Görsev Yener,

Dokuz Eylül University, Turkey

Reviewed by:

Margaret Ellen Flanagan, Northwestern Medicine, United States

Magda Tsolaki,

Aristotle University of

Thessaloniki, Greece

${ }^{*}$ Correspondence:

David A. Loeffler

dloeffler@beaumont.edu

Specialty section:

This article was submitted to

Dementia and Neurodegenerative

Diseases,

a section of the journal

Frontiers in Neurology

Received: 19 September 2019

Accepted: 29 April 2020

Published: 29 May 2020

Citation:

Loeffler DA (2020) AMBAR, an

Encouraging Alzheimer's Trial That

Raises Questions.

Front. Neurol. 11:459

doi: 10.3389/fneur.2020.00459

\section{AMBAR, an Encouraging Alzheimer's Trial That Raises Questions}

\author{
David A. Loeffler* \\ Beaumont Research Institute, Department of Neurology, Beaumont Health, Royal Oak, MI, United States
}

Grifols' recent Alzheimer Management by Albumin Replacement ("AMBAR") study investigated the effects of plasmapheresis with albumin replacement, plus intravenous immunoglobulin (IVIG) in some subjects, in patients with mild-to-moderate Alzheimer's disease $(A D)$. AMBAR was a phase Ilb trial in the United States and a phase III trial in Europe. There were three treatment groups (plasmapheresis with albumin replacement; plasmapheresis with low dose albumin and IVIG; plasmapheresis with high dose albumin and IVIG) and sham-treated controls. Disease progression in pooled treated patients was $66 \%$ less than control subjects based on ADAS-Cog scores $(p=0.06)$ and $52 \%$ less based on ADCS-ADL scores $(p=0.03)$. Moderate AD patients had $61 \%$ less progression, based on both ADAS-Cog and ADCS-ADL scores, than their sham-treated counterparts ( $p$-values 0.05 and 0.002), and their CDR-Sb scores declined 53\% less than their sham-treated counterparts. However, ADAS-Cog and ADCS-ADL scores were not significantly different between actively-treated and sham-treated mild AD patients, although CDR-Sb scores improved vs. baseline for treated mild AD patients. Patients administered both IVIG and albumin had less reduction in brain glucose metabolism than sham-treated patients. Questions raised by these findings include: what mechanism(s) contributed to slowing of disease progression? Is this approach as effective in mild $A D$ as in moderate AD? Must IVIG be included in the protocol? Does age, sex, or ApoE genotype influence treatment response? Does the protocol increase the risk for amyloid-related imaging abnormalities? How long does disease progression remain slowed post-treatment? A further study should allow this approach to be optimized.

Keywords: Abeta, albumin, Alzheimer's, AMBAR, clinical trial, intravenous immunoglobulin, peripheral sink hypothesis, plasma exchange

\section{INTRODUCTION}

The amyloid hypothesis (1) led to efforts to treat Alzheimer's disease (AD) by reducing brain $A \beta$, including vaccination (2), anti-A $\beta$ antibodies (3-7), $A \beta$ aggregation inhibitors (8), $\beta$-secretase inhibitors (9), and $\gamma$-secretase modulators (10), and inhibitors (11). The failure of these approaches to slow $\mathrm{AD}$ 's progression [with the possible exception of anti- $\mathrm{A} \beta$ antibody Aducanumab, whose recently released findings are controversial (12)] resulted in increased targeting of tau, the main component of neurofibrillary tangles (NFTs), by vaccination (13), anti-tau antibodies (14), tau aggregation inhibitors (15), and kinase inhibitors (16). Other mechanisms which may contribute to AD's neuropathology including inflammation (17), oxidative stress (18), and excitotoxicity (19) have also been targeted, with negative results except for the N-methyl-d-aspartate receptor 
antagonist Memantine $\mathrm{HCl}$. Memantine and cholinesterase inhibitors are the only treatments currently approved by the United States Food and Drug Administration for AD; they provide symptomatic benefits to some patients but are not disease modifiers (20).

This Perspective will discuss the results, significance, possible mechanisms, and questions raised by the recently-completed Alzheimer Management by Albumin Replacement (“AMBAR”) study (ClinicalTrials.gov ID: NCT01561053) (21) performed by Grifols (Instituto Grifols, S.A.). AMBAR was registered as a phase IIb study in the United States and a phase III study in Europe. The protocol involved plasma removal and its replacement with therapeutic-grade human albumin, plus supplementation with intravenous immunoglobulin (IVIG) in some patients. The rationale for the study was that lowering plasma $A \beta$ levels by this approach might reduce brain levels of soluble $A \beta$, as predicted by the "peripheral sink hypothesis" $(22,23)$, possibly slowing AD's progression.

\section{BACKGROUND}

In vitro studies found that albumin inhibited $\mathrm{A} \beta$ aggregation (24) and neurotoxicity (25). However, plasma albumin from $\mathrm{AD}$ patients is more glycated and nitrotyrosinated than plasma from healthy subjects, reducing its ability to inhibit $A \beta$ aggregation (26). Grifols theorized that replacing AD patients' albumin with therapeutic-grade albumin should overcome this problem. Further, therapeutic-grade albumin should more effectively bind plasma $A \beta$ and sequester it than plasma albumin from $\mathrm{AD}$ patients. Albumin may protect neurons by additional mechanisms, including anti-oxidant $(27,28)$ and antiinflammatory $(29,30)$ activities. Because of albumin's anti-A $\beta$ effects, Grifols decided to explore the potential of its human plasma albumin Albutein ${ }^{\circledR}$ (31) for treating AD.

The peripheral sink hypothesis is based on the finding that administration of a monoclonal anti- $\mathrm{A} \beta$ antibody to a transgenic mouse $\mathrm{AD}$ model lowered brain $\mathrm{A} \beta$, despite apparent failure of the antibody to enter the brain $(22,23)$. This suggested that lowering plasma albumin might result in reduction of brain $A \beta$ by increasing movement of soluble $A \beta$ from brain into peripheral blood. The hypothesis assumes that soluble $A \beta$ is in equilibrium between brain and peripheral blood. Grifols theorized that because $\sim 90 \%$ of plasma $A \beta$ is bound to albumin (32), replacing $\mathrm{AD}$ patients' plasma with Albutein, which does not contain detectable $A \beta$ (33), should decrease plasma $A \beta$ (34). The hypothesis predicted that this would result in increased movement of soluble $A \beta$ out of the brain. Some studies have supported the peripheral sink hypothesis (35-37) but others have not (38-40).

\section{PRELIMINARY STUDIES}

In 2005 Grifols performed a pilot study (41) with seven mildto-moderate $\mathrm{AD}$ patients who underwent plasma removal with Albutein replacement twice weekly for 3 weeks with a 6months follow-up period. No clear patterns were detected for changes in plasma $A \beta 40$ or $A \beta 42$. CSF $A \beta 40$ decreased slightly during plasma exchange with a greater decrease in CSF $\mathrm{A} \beta 42$, and both $\mathrm{A} \beta$ concentrations returned to near baseline 6 months post-treatment. Mini-Mental State Examination (MMSE) and Alzheimer's Disease Assessment Scale-Cognitive subscale (ADAS-Cog) scores changed little, while imaging suggested increased hippocampal volume and increased frontal and temporal cortex perfusion. In a 1-year extension of the study, a more sensitive method for measuring plasma $A \beta 40$ and $A \beta 42$ revealed a "sawtooth" pattern: $A \beta$ decreased after each plasma exchange, and returned to baseline before the next procedure. CSF $A \beta 40$ and $A \beta 42$ remained relatively stable during the extension. Grifols concluded from these findings that the approach was feasible to consider for treatment of $\mathrm{AD}$ patients.

In 2007 Grifols performed a phase II trial (ClinicalTrials.gov Identifier: NCT00742417) $(42,43)$ with this approach, involving 19 actively-treated and 20 sham-treated mild-to-moderate AD patients. The treatment group underwent plasma removal with Albutein replacement twice weekly for 3 weeks, then weekly for 6 weeks followed by every 2 weeks for 12 weeks. Control patients underwent simulated procedures so neither patients nor study raters knew patient group assignments. Parameters measured were similar to those in the pilot study, following patients for 6 months. The adjusted (least-squares) mean CSF A 342 concentration was "marginally higher" $(p=0.07)$, in the treatment group compared to the control group, after the last plasma exchange compared to the mean baseline value, while the change from baseline in CSF A $\beta 40$ was not significantly different between groups. A sawtooth pattern for plasma A $\beta 40$ and $A \beta 42$ was again found in the treatment group. MMSE and ADAS-Cog scores tended to be higher in the treatment group than in the control group at the end of treatment and followup periods but between-group differences were not significant (ADAS- $\operatorname{Cog} p=0.09$ at week 21, MMSE $p=0.08$ at week 44). Higher scores in the treatment group were found for some tests of language and attention, but worse scores for the Neuropsychiatric Inventory (NPI) (44). The frequency of adverse events was similar between groups.

\section{AMBAR}

AMBAR was a multicenter, randomized, double-blind, placebocontrolled study in which patients were treated for 14 months. The study included 496 patients with mild to moderate AD (MMSE scores 18-26), divided among three groups of activelytreated subjects and a sham-treated control group. All activelytreated patients initially underwent removal of 2,500-3,000 mL of plasma ("high-volume" plasma exchange), replaced by the same volume of Albutein 5\%, weekly for 6 weeks through a peripheral vein or a central venous catheter placed in the subclavian or jugular vein. This was followed by 12 months of monthly "low-volume" plasma exchange in which $650-880 \mathrm{~mL}$ of plasma was removed and replaced with $100 \mathrm{~mL}$ of Albutein 20\% (20 g Albutein), $100 \mathrm{~mL}$ of Albutein 20\% plus $200 \mathrm{~mL}$ of Grifols' IVIG Flebogamma 5\% DIF (10 g Flebogamma) ("low albumin/low IVIG” group), or $200 \mathrm{~mL}$ of Albutein 20\% (40 g Albutein) plus $400 \mathrm{~mL}$ of Flebogamma 5\% DIF (20 g Flebogamma) ("high albumin/high IVIG" group). This second stage of plasmapheresis was performed via a peripheral vein. ADAS-Cog 
and Alzheimer's Disease Cooperative Study-Activities of Daily Living (ADCS-ADL) scores were measured at baseline, after initial plasmapheresis, at 7, 9, and 12 months of second stage plasmapheresis, and at 14 months after finishing plasmapheresis. Primary outcome measures were changes in ADAS-Cog and ADCS-ADL scores between baseline and endpoint. Secondary outcome measures were changes in cognitive, functional, and behavioral tests, measures of disease progression, and alterations in CSF p-tau, total tau, $\mathrm{A} \beta 40$, and $\mathrm{A} \beta 42$, plasma $\mathrm{A} \beta 40$ and $\mathrm{A} \beta 42$, brain structure, and brain glucose metabolism. Statistical analyses of changes vs. sham-treated controls in ADAS-Cog and ADCSADL scores were performed on data from pooled treatment subjects and, in pre-specified analyses, from patients with mild AD (MMSE 22-26) and moderate AD (MMSE 18-21).

AMBAR's topline results (45) indicated that treatment groups averaged 50 to $75 \%$ less worsening of ADAS-Cog scores and 42 to $70 \%$ less worsening of ADCS-ADL scores than control subjects. Pooled data from treated subjects showed that these patients declined, on average, $66 \%$ less than control subjects based on ADAS-Cog scores $(p=0.06)$ and $52 \%$ less based on ADCS-ADL scores $(p=0.03)$. Analyses of changes from baseline to endpoint in patients with moderate $\mathrm{AD}$ found $61 \%$ less disease progression, based on both ADAS-Cog and ADCS-ADL scores, than shamtreated moderate AD patients ( $p=0.05$ for ADAS-Cog, 0.002 for ADCS-ADL). Although some slowing of disease progression was also found in the treated patients with mild $\mathrm{AD}$, a similar pattern was unexpectedly seen for sham-treated mild $\mathrm{AD}$ patients so the between-group differences in ADAS-Cog and ADCS-ADL scores were not statistically significant.

At the 2019 International Congress on Alzheimer's and Parkinson's (AD/PD) $(46,47)$ Grifols reported significant differences at endpoint between patients in the high albumin/high IVIG treatment arm and the control subjects in tests of memory, language, processing speed, and quality of life. Actively-treated moderate $\mathrm{AD}$ patients performed significantly better than their sham-treated counterparts on tests of memory and quality of life, while mild $\mathrm{AD}$ patients performed significantly better than their control counterparts on tests of language and processing speed. A low rate of adverse events was reported, occurring mainly during highvolume plasma exchange. CSF $A \beta 42$ was stable in treated patients while decreasing in sham-treated patients (results for $\mathrm{A} \beta 40$ were not shown), while CSF phosphorylated and total tau increased less in treated patients than in controls. At the 2019 Alzheimer's Association International Conference (48) Grifols reported that Alzheimer's Disease Cooperative Study-Clinical Global Impression of Change (ADCS-CGIC) scores had remained stable in all treatment groups, and these patients had declined, on average, $71 \%$ less than controls on the Clinical Dementia Rating-Sum of Boxes (CDR-Sb) scale $(49,50)$. CDR-Sb scores for mild AD patients improved while moderate $\mathrm{AD}$ patients' scores declined $53 \%$ less than their sham-treated counterparts (51). Final results presented at the 2019 Clinical Trials on Alzheimer's Disease (CTAD) Conference indicated that patients receiving both Flebogamma and Albutein had less reduction in brain glucose metabolism than controls.

\section{DISCUSSION}

The results from AMBAR are encouraging, in contrast to the other approaches that have been tried to slow AD's progression. A review of AD trials for the period between 2002 and 2012 concluded that the overall success rate was $0.4 \%$ (52). No new drugs have been approved for treatment of AD since 2003, although Namzaric, which combines Memantine and Donepezil, received FDA approval in 2014.

Perhaps the most important question raised by AMBAR's findings is: what mechanism was responsible for slowing disease progression? Identifying this mechanism would provide support for further efforts to slow AD's progression by means of the same mechanism. Among the mechanisms that could have contributed to AMBAR's slowing of disease progression are reductions in neurotoxic $A \beta$ species, tau pathology, neuroinflammation, oxidative stress, microcirculatory deficits, and neurotoxic autoantibodies. These will be discussed below.

\section{Reduced $A \beta$}

Although both $A \beta 40$ and $A \beta 42$ were measured in CSF, results were reported only for $A \beta 42(47,49)$, whose concentrations were stable in treated patients while decreasing in control patients. Whether brain levels of $A \beta$ were lowered is unclear. CSF $A \beta 42$ is reduced in $\mathrm{AD}$ (53), possibly due to sequestration of $A \beta 42$ as insoluble fibrils (54). Lowering soluble $A \beta 42$ in brain could either increase or decrease CSF A $\beta 42$, depending on its rates of clearance from brain to CSF and from CSF to peripheral blood. A future study should measure CSF levels of $A \beta$ soluble oligomers, which may be A $\beta$ 's most neurotoxic conformation (55). An assay for their measurement in CSF was recently reported (56). To determine if plaque counts were lowered, PET A $\beta$ imaging could be performed $(57,58)$. Post-mortem evaluation of plaques and NFT should also be considered on subjects who pass away during a future study with the AMBAR protocol. Plaque densities are less strongly correlated than NFTs with cognitive loss in AD patients $(59,60)$, so even if plaque counts decreased relative to sham-treated subjects, this would be unlikely to be the sole mechanism responsible for slowing of disease progression. In the AN1792 A $\beta$ vaccination trial, for example, despite marked reductions in plaque counts found in subsequent post-mortem studies $(61,62)$, clinical progression was not slowed (2). Finally, it would be worthwhile to determine the incidence of amyloidrelated imaging abnormalities (ARIA). ARIA refers to imaging abnormalities (often not associated with symptoms) associated with increased movement of $A \beta$ from brain after treatment with anti- $\mathrm{A} \beta$ antibodies $(5,63,64)$.

\section{Reduced Tau Pathology}

The amyloid hypothesis (1) suggests that tau pathology in $\mathrm{AD}$ develops downstream from $\mathrm{A} \beta$ deposition; therefore if the AMBAR protocol reduced brain $A \beta$ levels, this could have secondarily decreased tau pathology. Total and phosphorylated tau (p-tau) levels in CSF are increased in AD (65). CSF levels of total and p-tau increased less in AMBAR's plasma exchangetreated patients than in sham-treated patients (47), suggesting that tau pathology may have been reduced. A future study should 
examine this issue by PET imaging (66). CSF concentrations of soluble tau oligomers could also be measured (67).

\section{Reduced Inflammation}

Chronic systemic inflammation has been associated with increased risk for development (68) and progression (69) of AD. Plasmapheresis removes inflammatory cytokines from peripheral blood (70), so the AMBAR protocol could have reduced systemic inflammation via this mechanism, perhaps decreasing brain inflammation as a consequence. Inflammatory cytokines and chemokines, as well as complement proteins and activation fragments, are readily measured in CSF (71-75), so it would be useful to measure these. Activated microglia (76) and astrocytosis (77) can be imaged in the brain via PET, so these procedures should also be considered.

\section{Reduced Oxidative Stress}

Oxidative stress in present in $\mathrm{AD}$ and may contribute to its pathogenesis (78). The AMBAR protocol could have directly reduced brain oxidative stress due to the anti-oxidant actions of albumin $(79,80)$ if CSF levels of albumin were sufficient to exert these effects. Conflicting reports have been published regarding the effects of plasmapheresis on oxidative stress (81-84). This could be examined in a future study by measuring CSF oxidative stress biomarkers such as 8-hydroxy-2'-deoxyguanosine (85), 8isoprostane (86), protein sulfhydryls (87), and total antioxidant capacity (88).

\section{Reduction of Microcirculatory Deficits}

Plasmapheresis with removal of low density lipoproteins is used to treat conditions such as familial hypercholesterolemia and peripheral arterial disease. This improves microcirculation and lowers systemic oxidative stress (81). AMBAR's inclusion criteria included diagnosis of AD based on NINCDS-ADRDA criteria, and imaging showing the absence of cerebrovascular disease [which includes stroke, transient ischemic attack (TIA), subarachnoid hemorrhage, and vascular dementia (89)], so AMBAR's participants likely did not have vascular dementia. However, AMBAR's exclusion criteria did not include lipid profile abnormalities, so improved microcirculation might have contributed to slowing of disease progression in some patients. Correlations between plasma lipid profile components and $\mathrm{AD}$ progression could be examined in Grifols' next study.

\section{Removal of Autoimmune Antibodies}

Plasmapheresis is used to treat some autoimmune disorders because it removes pathogenic auto-antibodies as well as complement proteins and cytokines from plasma (90, 91). Some investigators have suggested that $\mathrm{AD}$ may be an autoimmune disorder $(92,93)$ although this view is not generally accepted. If autoantibodies do play a role in $\mathrm{AD}$ pathogenesis, then their removal may have contributed to AMBAR's slowing of $\mathrm{AD}$ progression, although this scenario is considered to be unlikely. In the next study with the AMBAR protocol, the presence and titers of CSF antihippocampal antibodies (94) could be compared in pre- and post-treatment CSF samples from both actively-treated and sham-treated subjects.

In addition to these mechanisms, plasma exchange removes many other proteins $(42,95)$ so the possibility is not ruled out that slowing of AD's progression could have been due to lowering of brain levels of unidentified proteins (96).

Grifols reported a low rate of adverse events in AMBAR, many of which occurred during the initial stage of plasmapheresis, which, for some patients, involved placement and 6-weeks maintenance of a central venous catheter. In the phase II trial, anxiety relating to these catheters was suggested to contribute to worse NPI scores in treated patients than in sham-treated patients (42). The decision whether to perform the initial plasma exchange through a peripheral or central vein was "based on the individual characteristics of the patient" (97). The saw-tooth pattern of plasma $A \beta 40$ and $A \beta 42$ was found for both the "highvolume" and "low-volume" stages of plasma exchange, so a future study should clarify if the high-volume plasma exchange (and central venous catheter) is actually necessary.

It is unclear if AMBAR's protocol is as effective in slowing disease progression in mild $\mathrm{AD}$ as in moderate $\mathrm{AD}$; this needs clarification. Changes from baseline to endpoint in ADAS-Cog and ADCS-ADL scores indicated significant slowing of progression in the actively-treated moderate $\mathrm{AD}$ patients compared to sham-treated moderate $\mathrm{AD}$ patients, but no significant differences were found in these scores between actively-treated and sham-treated mild $\mathrm{AD}$ patients; however, $\mathrm{CDR}-\mathrm{Sb}$ scores were improved for actively-treated vs. shamtreated mild $\mathrm{AD}$ patients. Although positive effects were reported for mild $\mathrm{AD}$ patients in tests of language and processing speed, these effects were notably absent for tests of memory.

Two of AMBAR's treatment groups included Flebogamma. Disappointing results were obtained with IVIG products in phase II and phase III AD trials $(98,99)$ so IVIG is no longer being considered for $\mathrm{AD}$ monotherapy. AMBAR's most positive results with regard to slowing of disease progression were in the high albumin/high IVIG treatment group (46), and neuroimaging similarly found that less reduction in brain glucose metabolism vs. sham-treated patients was found "particularly in patients receiving both albumin and immunoglobulin" (49). IVIG supplies are limited (100) so the supply of Flebogamma could be insufficient to meet the demand for it if the AMBAR protocol receives regulatory approval and the protocol includes Flebogamma. A further concern with IVIG is that it increases serum viscosity (101), predisposing to thromboemboli, particularly in individuals who are immobile or have vascular disease (102).

Shortages of human albumin have also been reported (103), raising the question of whether recombinant human albumin (rHA) could be substituted for human albumin in AMBAR's protocol. rHA has been reported to have a safety, tolerability, and pharmacokinetic/pharmacodynamic profile similar to human albumin (104).

Additional questions about the treatment approach used in AMBAR which need to be answered include the influence of patient age, sex, and ApoE status on slowing of $\mathrm{AD}$ progression, the duration of slowing of cognitive and functional decline once 
treatment is stopped, and whether the protocol is feasible in the many $\mathrm{AD}$ patients who are medically frail, particularly if maintenance of a central venous catheter is required.

\section{CONCLUSIONS}

AMBAR's findings are encouraging, despite the questions they raise. A further study offers Grifols the opportunity to address these issues, and to optimize the protocol.

\section{REFERENCES}

1. Hardy J, Allsop D. Amyloid deposition as the central event in the aetiology of alzheimer's disease. Trends Pharmacol Sci. (1991) 12:3838. doi: 10.1016/0165-6147(91)90609-V

2. Gilman S, Koller M, Black RS, Jenkins L, Griffith SG, Fox NC, et al. Clinical effects of Abeta immunization (AN1792) in patients with $\mathrm{AD}$ in an interrupted trial. Neurology. (2005) 64:1553-62. doi: 10.1212/01.WNL.0000159740.16984.3C

3. Doody RS, Thomas RG, Farlow M, Iwatsubo T, Vellas B, Joffe S, et al. Phase 3 trials of solanezumab for mild-to-moderate alzheimer's disease. $N$ Engl $\mathrm{J}$ Med. (2014) 370:311-21. doi: 10.1056/NEJMoa1312889

4. Sevigny J, Chiao P, Bussière T, Weinreb PH, Williams L, Maier M, et al. The antibody aducanumab reduces $\mathrm{A} \beta$ plaques in alzheimer's disease. Nature. (2016) 537:50-6. doi: 10.1038/nature19323

5. Ostrowitzki S, Lasser RA, Dorflinger E, Scheltens P, Barkhof F, Nikolcheva T, et al. A phase III randomized trial of gantenerumab in prodromal alzheimer's disease. Alzheimers Res Ther. (2017) 9:95. doi: 10.1186/s13195-017-0318-y

6. Cummings JL, Cohen S, van Dyck CH, Brody M, Curtis C, Cho W, et al. ABBY: A phase 2 randomized trial of crenezumab in mild to moderate alzheimer disease. Neurology. (2018) 90:e1889-97. doi: 10.1212/WNL.0000000000005550

7. Salloway S, Sperling R, Fox NC, Blennow K, Klunk W, Raskind M, et al. Two phase 3 trials of bapineuzumab in mild-to-moderate alzheimer's disease. $N$ Engl J Med. (2014) 370:322-33. doi: 10.1056/NEJMoa1304839

8. Wang $\mathrm{Q}, \mathrm{Yu} \mathrm{X}, \mathrm{Li} \mathrm{L}$, Zheng J. Inhibition of amyloid- $\beta$ aggregation in Alzheimer's disease. Curr Pharm Des. (2014) 20:1223-43. doi: 10.2174/13816128113199990068

9. Moussa CE. Beta-secretase inhibitors in phase I and phase II clinical trials for alzheimer's disease. Expert Opin Investig Drugs. (2017) 26:113136. doi: 10.1080/13543784.2017.1369527

10. Green RC, Schneider LS, Amato DA, Beelen AP, Wilcock G, Swabb EA, et al. Effect of tarenflurbil on cognitive decline and activities of daily living in patients with mild alzheimer disease: a randomized controlled trial. JAMA. (2009) 302:2557-64. doi: 10.1001/jama.2009.1866

11. Doody RS, Raman R, Farlow M, Iwatsubo T, Vellas B, Joffe S, et al. A phase 3 trial of semagacestat for treatment of alzheimer's disease. N Engl J Med. (2013) 369:341-50. doi: 10.1056/NEJMoa1210951

12. New York Times. That New Alzheimer's Drug? Don't Get Your Hopes Up Yet. (2019). Available online at: https://www.nytimes.com > health > alzheimersdementia-aducanumab (accessed December 29, 2019).

13. Novak P, Schmidt R, Kontsekova E, Zilka N, Kovacech B, Skrabana R, et al. Safety and immunogenicity of the tau vaccine AADvac1 in patients with alzheimer's disease: a randomised, double-blind, placebo-controlled, phase 1 trial. Lancet Neurol. (2017) 16:123-34. doi: 10.1016/S1474-4422(16)30331-3

14. Courade JP, Angers R, Mairet-Coello G, Pacico N, Tyson K, Lightwood $\mathrm{D}$, et al. Epitope determines efficacy of therapeutic anti-Tau antibodies in a functional assay with human alzheimer tau. Acta Neuropathol. (2018) 136:729-45. doi: 10.1007/s00401-018-1911-2

15. Cisek K, Cooper GL, Huseby CJ, Kuret J. Structure and mechanism of action of tau aggregation inhibitors. Curr Alzheimer Res. (2014) 11:91827. doi: 10.2174/1567205011666141107150331

16. Lin $\mathrm{CH}$, Hsieh YS, Wu YR, Hsu CJ, Chen HC, Huang WH, et al. Identifying GSK-3 $\beta$ kinase inhibitors of alzheimer's disease: virtual screening, enzyme, and cell assays. Eur J Pharm Sci. (2016) 89:119. doi: 10.1016/j.ejps.2016.04.012

\section{AUTHOR CONTRIBUTIONS}

DL wrote and revised the manuscript.

\section{FUNDING}

Funding was provided by donations to the Beaumont Foundation to support Alzheimer's research in the Beaumont Research Institute.

17. Calsolaro V, Edison P. Neuroinflammation in alzheimer's disease: current evidence and future directions. Alzheimers Dement. (2016) 12:71932. doi: 10.1016/j.jalz.2016.02.010

18. Butterfield DA. Amyloid beta-peptide (1-42)-induced oxidative stress and neurotoxicity: implications for neurodegeneration in alzheimer's disease brain. A review. Free Radic Res. (2002) 36:1307-13. doi: 10.1080/1071576021000049890

19. Wang R, Reddy PH. Role of glutamate and NMDA receptors in alzheimer's disease. J Alzheimers Dis. (2017) 57:1041-8. doi: 10.3233/JAD-160763

20. Galimberti D, Scarpini E. Disease-modifying treatments for alzheimer's disease. Ther Adv Neurol Disord. (2011) 4:20316. doi: $10.1177 / 1756285611404470$

21. Grifols SA. The AMBAR study. (2019). Available online at: https://www. grifols.com > the-ambar-study (accessed December 29, 2019).

22. DeMattos RB, Bales KR, Cummins DJ, Dodart JC, Paul SM, Holtzman DM. Peripheral anti-Abeta antibody alters CNS and plasma Abeta clearance and decreases brain Abeta burden in a mouse model of alzheimer's disease. Proc Natl Acad Sci USA. (2001) 98:8850-5. doi: 10.1073/pnas.151261398

23. DeMattos RB, Bales KR, Cummins DJ, Paul SM, Holtzman DM. Brain to plasma amyloid-beta efflux: a measure of brain amyloid burden in a mouse model of Alzheimer's disease. Science. (2002) 295:22647. doi: 10.1126/science. 1067568

24. Reyes Barcelo AA, Gonzalez-Velasquez FJ, Moss MA. Soluble aggregates of the amyloid-beta peptide are trapped by serum albumin to enhance amyloid-beta activation of endothelial cells. J Biol Eng. (2009) 3:5. doi: 10.1186/1754-1611-3-5

25. Vega L, Arroyo AA, Tabernero A, Medina JM. Albumin-blunted deleterious effect of amyloid-beta by preventing the internalization of the peptide into neurons. J Alzheimers Dis. (2009) 17:795-805. doi: 10.3233/JAD-2009-1093

26. Ramos-Fernández E, Tajes M, Palomer E, Ill-Raga G, Bosch-Morató M, Guivernau B, et al. Posttranslational nitro-glycative modifications of albumin in alzheimer's disease: implications in cytotoxicity and amyloid- $\beta$ peptide aggregation. J Alzheimers Dis. (2014) 40:643-57. doi: 10.3233/JAD-130914

27. Prajapati KD, Sharma SS, Roy N. Current perspectives on potential role of albumin in neuroprotection. Rev Neurosci. (2011) 22:35563. doi: 10.1515/rns.2011.028

28. Colombo G, Clerici M, Giustarini D, Rossi R, Milzani A, DalleDonne I. Redox albuminomics: oxidized albumin in human diseases. Antioxid Redox Signal. (2012) 17:1515-27. doi: 10.1089/ars.201 2.4702

29. Thomas GW, Rael LT, Mains CW, Slone D, Carrick MM, Bar-Or R, et al. Anti-inflammatory activity in the low molecular weight fraction of commercial human serum albumin (LMWF5A). J Immunoassay Immunochem. (2016) 37:55-67. doi: 10.1080/15321819.2015.1047516

30. Ezra A, Rabinovich-Nikitin I, Rabinovich-Toidman P, Solomon B. Multifunctional effect of human serum albumin reduces alzheimer's disease related pathologies in the $3 \mathrm{xTg}$ mouse model. J Alzheimers Dis. (2016) 50:175-88. doi: 10.3233/JAD-150694

31. Albumin (Human) U.S.P. Albutein $® 25 \%$ Solution. Los Angeles, CA: Grifols Biologicals Inc. (2006).

32. Biere AL, Ostaszewski B, Stimson ER, Hyman BT, Maggio JE, Selkoe DJ. Amyloid beta-peptide is transported on lipoproteins and albumin in human plasma. J Biol Chem. (1996) 271:32916-22. doi: 10.1074/jbc.271.51.32916

33. Costa M, Ortiz AM, Jorquera JI. Therapeutic albumin binding to remove amyloid- $\beta$. J Alzheimers Dis. (2012) 29:15970. doi: 10.3233/JAD-2012-111139 
34. Boada M, Ramos-Fernández E, Guivernau B, Muñoz FJ, Costa M, Ortiz $\mathrm{AM}$, et al. Treatment of alzheimer disease using combination therapy with plasma exchange and haemapheresis with albumin and intravenous immunoglobulin: rationale and treatment approach of the AMBAR (Alzheimer Management By Albumin Replacement) study. Neurologia. (2016) 31:473-81. doi: 10.1016/j.nrleng.2014.02.009

35. Matsuoka Y, Saito M, LaFrancois J, Saito M, Gaynor K, Olm V, et al. Novel therapeutic approach for the treatment of alzheimer's disease by peripheral administration of agents with an affinity to beta-amyloid. J Neurosci. (2003) 23:29-33. doi: 10.1523/JNEUROSCI.23-01-00029.2003

36. Vasilevko V, Xu F, Previti ML, Van Nostrand WE, Cribbs DH. Experimental investigation of antibody-mediated clearance mechanisms of amyloidbeta in CNS of Tg-SwDI transgenic mice. J Neurosci. (2007) 27:1337683. doi: 10.1523/JNEUROSCI.2788-07.2007

37. Sehgal N, Gupta A, Valli RK, Joshi SD, Mills JT, Hamel E, et al. Withania somnifera reverses alzheimer's disease pathology by enhancing low-density lipoprotein receptor-related protein in liver. Proc Natl Acad Sci USA. (2012) 109:3510-5. doi: 10.1073/pnas.1112209109

38. Georgievska B, Gustavsson S, Lundkvist J, Neelissen J, Eketjäll S, Ramberg $\mathrm{V}$, et al. Revisiting the peripheral sink hypothesis: inhibiting BACE1 activity in the periphery does not alter $\beta$-amyloid levels in the CNS. J Neurochem. (2015) 132:477-86. doi: 10.1111/jnc.12937

39. Walker JR, Pacoma R, Watson J, Ou W, Alves J, Mason DE, et al. Enhanced proteolytic clearance of plasma $A \beta$ by peripherally administered neprilysin does not result in reduced levels of brain $A \beta$ in mice. J Neurosci. (2013) 33:2457-64. doi: 10.1523/JNEUROSCI.3407-12.2013

40. Henderson SJ, Andersson C, Narwal R, Janson J, Goldschmidt TJ, Appelkvist P, et al. Sustained peripheral depletion of amyloid- $\beta$ with a novel form of neprilysin does not affect central levels of amyloid- $\beta$. Brain. (2014) 137:55364. doi: 10.1093/brain/awt308

41. Boada M, Ortiz P, Anaya F, Hernández I, Muñoz J, Núñez L, et al. Amyloidtargeted therapeutics in alzheimer's disease: use of human albumin in plasma exchange as a novel approach for Abeta mobilization. Drug News Perspect. (2009) 22:325-39. doi: 10.1358/dnp.2009.22.6.1395256

42. Boada M, Anaya F, Ortiz P, Olazarán J, Shua-Haim JR, Obisesan TO, et al. Efficacy and safety of plasma exchange with $5 \%$ albumin to modify cerebrospinal fluid and plasma amyloid- $\beta$ concentrations and cognition outcomes in alzheimer's disease patients: a multicenter, randomized, controlled clinical trial. J Alzheimers Dis. (2017) 56:12943. doi: 10.3233/JAD-160565

43. Cuberas-Borrós G, Roca I, Boada M, Tárraga L, Hernández I, Buendia $\mathrm{M}$, et al. Longitudinal neuroimaging analysis in mild-moderate alzheimer's disease patients treated with plasma exchange with $5 \%$ human albumin. $J$ Alzheimers Dis. (2018) 61:321-32. doi: 10.3233/JAD-170693

44. Cummings JL. The neuropsychiatric inventory: assessing psychopathology in dementia patients. Neurology. (1997) 48:S10-6. doi: 10.1212/WNL.48.5_Suppl_6.10S

45. Grifols. "Grifols AMBAR results demonstrate a significant reduction in the progression of moderate Alzheimer's Disease." (2018) Available online at: https://www.grifols.com/en/view-news/-/news/grifols-ambar-resultsdemonstrate-a-significant-reduction-in-the-progression-of-moderatealzheimers-disease (accessed August 28, 2019).

46. Grifols. Grifols presents new data to support the effectiveness of its clinical trial to treat Alzheimer's. (2019) Available online at: https://www.grifols. com/en/view-news/-/news/grifols-presents-new-data-to-support- theeffectiveness-of-its-clinical-trial-to-treat-alzheimer-s (accessed August 28, 2019).

47. Pharmaceutical Technology.com, AMBAR study on new treatments for Alzheimer's and Parkinson's discussed at AD/PD 2019. (2019). Available online at: https://www.pharmaceutical-technology.com/comment/ambarstudy-on-new-treatments-for-alzheimers-and-parkinsons-discussed-atad-pd-2019/ (accessed August 28, 2019).

48. Newswire PR, Grifols presents additional encouraging Alzheimer's trial results at AAIC. (2019). Available online at: https://www.prnewswire.com/newsreleases/grifols-presents-additional-encouraging-alzheimers-trial-resultsat-aaic-300885408.html (accessed August 28, 2019).

49. Grifols SA. The results. (2019). Available online at: https://www.grifols.com/ en/the-results (accessed December 29, 2019).
50. Williams MM, Storandt M, Roe CM, Morris JC. Progression of alzheimer's disease as measured by clinical dementia rating sum of boxes scores. Alzheimers Dement. (2013) 9:S39-44. doi: 10.1016/j.jalz.2012.01.005

51. marketscreener.com. Grifols: presents additional encouraging Alzheimer's trial results at AAIC. (2019). Available online at: https://www. marketscreener.com , GRIFOLS-SA-ADR-11104734, news (accessed December 30, 2019).

52. Cummings JL, Morstorf T, Zhong K. Alzheimer's disease drug-development pipeline: few candidates, frequent failures. Alzheimers Res Ther. (2014) 6:37. doi: $10.1186 /$ alzrt269

53. Spies PE, Verbeek MM, van Groen T, Claassen JA. Reviewing reasons for the decreased CSF Abeta42 concentration in alzheimer disease. Front Biosci. (2012) 17:2024-34. doi: 10.2741/4035

54. Kuo YM, Emmerling MR, Vigo-Pelfrey C, Kasunic TC, Kirkpatrick JB, Murdoch GH, et al. Water-soluble Abeta (N-40, N-42) oligomers in normal and alzheimer disease brains. J Biol Chem. (1996) 271:407781. doi: 10.1074/jbc.271.8.4077

55. Lambert MP, Barlow AK, Chromy BA, Edwards C, Freed R, Liosatos M, et al. Diffusible, nonfibrillar ligands derived from Abeta1-42 are potent central nervous system neurotoxins. Proc Natl Acad Sci USA. (1998) 95:644853. doi: 10.1073/pnas.95.11.6448

56. Yang T, Dang Y, Ostaszewski B, Mengel D, Steffen V, Rabe C, et al. Target engagement in an alzheimer trial: crenezumab lowers amyloid $\beta$ oligomers in cerebrospinal fluid. Ann Neurol. (2019) 86:215-24. doi: 10.1002/ana.25513

57. Klunk WE1, Engler H, Nordberg A, Wang Y, Blomqvist G, Holt DP, et al. Imaging brain amyloid in alzheimer's disease with pittsburgh compound-B. Ann Neurol. (2004) 55:306-19. doi: 10.1002/ana.20009

58. Clark CM, Schneider JA, Bedell BJ, Beach TG, Bilker WB, Mintun MA, et al. Use of florbetapir-PET for imaging beta-amyloid pathology. JAMA. (2011) 305:275-83. doi: 10.1001/jama.2010.2008

59. Arriagada PV, Growdon JH, Hedley-Whyte ET, Hyman BT. Neurofibrillary tangles but not senile plaques parallel duration and severity of alzheimer's disease. Neurology. (1992) 42:631-9. doi: 10.1212/WNL.42.3.631

60. Guillozet AL, Weintraub S, Mash DC, Mesulam MM. Neurofibrillary tangles, amyloid, and memory in aging and mild cognitive impairment. Arch Neurol. (2003) 60:729-36. doi: 10.1001/archneur.60.5.729

61. Boche D, Denham N, Holmes C, Nicoll JA. Neuropathology after active Abeta42 immunotherapy: implications for alzheimer's disease pathogenesis. Acta Neuropathol. (2010) 120:369-84. doi: 10.1007/s00401-010-0719-5

62. Nicoll JAR, Buckland GR, Harrison CH, Page A, Harris S, Love $\mathrm{S}$, et al. Persistent neuropathological effects 14 years following amyloid- $\beta$ immunization in Alzheimer's disease. Brain. (2019) 142:2113-26. doi: 10.1093/brain/awz142

63. Sperling R, Salloway S, Brooks DJ, Tampieri D, Barakos J, Fox NC, et al. Amyloid-related imaging abnormalities in patients with alzheimer's disease treated with bapineuzumab: a retrospective analysis. Lancet Neurol. (2012) 11:241-9. doi: 10.1016/S1474-4422(12)70015-7

64. Budd Haeberlein S, O'Gorman J, Chiao P, Bussière T, von Rosenstiel P, Tian $\mathrm{Y}$, et al. Clinical development of aducanumab, an anti-a $\beta$ human monoclonal antibody being investigated for the treatment of early alzheimer's disease. $J$ Prev Alzheimers Dis. (2017) 4:255-63. doi: 10.14283/jpad.2017.39

65. Sjögren M, Davidsson P, Tullberg M, Minthon L, Wallin A, Wikkelso C, et al. Both total and phosphorylated tau are increased in alzheimer's disease. $J$ Neurol Neurosurg Psychiatry. (2001) 70:624-630. doi: 10.1136/jnnp.70.5.624

66. Passamonti L, Vázquez Rodríguez P, Hong YT, Allinson KS, Williamson $\mathrm{D}$, Borchert RJ, et al. 18F-AV-1451 positron emission tomography in Alzheimer's disease and progressive supranuclear palsy. Brain. (2017) 140:781-91. doi: 10.1093/brain/aww340

67. Sengupta U, Portelius E, Hansson O, Farmer K, Castillo-Carranza D, Woltjer $\mathrm{R}$, et al. Tau oligomers in cerebrospinal fluid in alzheimer's disease. Ann Clin Transl Neurol. (2017) 4:226-35. doi: 10.1002/acn3.382

68. Tan ZS, Beiser AS, Vasan RS, Roubenoff R, Dinarello CA, Harris TB, et al. Inflammatory markers and the risk of alzheimer disease: the framingham study. Neurology. (2007) 68):1902-8. doi: 10.1212/01.wnl.0000263217.36439.da

69. Holmes C, Cunningham C, Zotova E, Woolford J, Dean C, Kerr S, et al. Systemic inflammation and disease progression in alzheimer disease. Neurology. (2009) 73:768-74. doi: 10.1212/WNL.0b013e3181b6bb95 
70. Yeh JH, Wang SH, Chien PJ, Shih CM, Chiu HC. Changes in serum cytokine levels during plasmapheresis in patients with myasthenia gravis. Eur J Neurol. (2009) 16:1318-22. doi: 10.1111/j.1468-1331.2009.02729.x

71. Galasko D, Montine TJ. Biomarkers of oxidative damage and inflammation in alzheimer's disease. Biomark Med. (2010) 4:27-36. doi: $10.2217 / \mathrm{bmm} .09 .89$

72. Janelidze S, Mattsson N, Stomrud E, Lindberg O, Palmqvist S, Zetterberg $\mathrm{H}$, et al. CSF biomarkers of neuroinflammation and cerebrovascular dysfunction in early Alzheimer disease. Neurology. (2018) 91:e867e77. doi: 10.1212/WNL.0000000000006082

73. Brosseron F, Traschütz A, Widmann CN, Kummer MP, Tacik P, Santarelli F, et al. Characterization and clinical use of inflammatory cerebrospinal fluid protein markers in alzheimer's disease. Alzheimers Res Ther. (2018) 10:25. doi: 10.1186/s13195-018-0353-3

74. Daborg J, Andreasson U, Pekna M, Lautner R, Hanse E, Minthon L, et al. Cerebrospinal fluid levels of complement proteins C3, C4 and CR1 in Alzheimer's disease. J Neural Transm. (2012) 119:78997. doi: $10.1007 /$ s00702-012-0797-8

75. Hu WT, Watts K, Tailor P, Nguyen TP, Howell JC, Lee RC, et al. CSF complement 3 and factor $\mathrm{H}$ are staging biomarkers in Alzheimer's disease. Acta Neuropathol Commun. (2016) 4:14. doi: 10.1186/s40478-016-0277-8

76. Chauveau F, Boutin H, Van Camp N, Dollé F, Tavitian B. Nuclear imaging of neuroinflammation: a comprehensive review of [11C]PK11195 challengers. Eur J Nucl Med Mol Imaging. (2008) 35):2304-19. doi: 10.1007/s00259-008-0908-9

77. Santillo AF, Gambini JP, Lannfelt L, Långström B, Ulla-Marja L, Kilander $\mathrm{L}$, et al. In vivo imaging of astrocytosis in alzheimer's disease: an C-Ldeuteriodeprenyl and PIB PET study. Eur J Nucl Med Mol Imaging. (2011) 38:2202-8. doi: 10.1007/s00259-011-1895-9

78. Wang X, Wang W, Li L, Perry G, Lee HG, Zhu X. Oxidative stress and mitochondrial dysfunction in alzheimer's disease. Biochim Biophys Acta. (2014) 1842:1240-7. doi: 10.1016/j.bbadis.2013.10.015

79. Roche M, Rondeau P, Singh NR, Tarnus E, Bourdon E. The antioxidant properties of serum albumin. FEBS Lett. (2008) 582:1783-7. doi: 10.1016/j.febslet.2008.04.057

80. Taverna M, Marie AL, Mira JP, Guidet B. Specific antioxidant properties of human serum albumin. Ann Intensive Care. (2013) 3:4. doi: 10.1186/2110-5820-3-4

81. Sato M, Amano I. Changes in oxidative stress and microcirculation by low-density lipoprotein apheresis. Ther Apher Dial. (2003) 7:41924. doi: 10.1046/j.1526-0968.2003.00078.x

82. Umgelter A, Reindl W, Lutz J, Kreymann B, Ronco C, Huber W, et al. Treatment of septic patients with an arginine-based endotoxin adsorber column improves hemodynamics and reduces oxidative stress: results of a feasibility study. Blood Purif. (2008) 26:333-9. doi: 10.1159/000132464

83. Nakae H, Igarashi T, Tajimi K. Selective plasma exchange with dialysis in patients with acute liver failure. Ther Apher Dial. (2012) 16:46771. doi: 10.1111/j.1744-9987.2012.01112.x

84. Gangemi S, Allegra A, Sciarrone P, Russo S, Cristani M, Gerace D, et al. Effect of therapeutic plasma exchange on plasma levels of oxidative biomarkers in a patient with thrombotic thrombocytopenic purpura. Eur J Haematol. (2015) 94:368-73. doi: 10.1111/ejh.12378

85. Valavanidis A, Vlachogianni T, Fiotakis C. 8-hydroxy-2' -deoxyguanosine (8-OHdG): A critical biomarker of oxidative stress and carcinogenesis. J Environ Sci Health C Environ Carcinog Ecotoxicol Rev. (2009) 27:12039. doi: 10.1080/10590500902885684

86. Morrow JD, Minton TA, Roberts LJ 2nd. The F2-isoprostane, 8-epi-prostaglandin F2 alpha, a potent agonist of the vascular thromboxane/endoperoxide receptor, is a platelet thromboxane/endoperoxide receptor antagonist. Prostaglandins. (1992) 44:155-63. doi: 10.1016/0090-6980(92)90077-7

87. Bayir H, Kagan VE, Tyurina YY, Tyurin V, Ruppel RA, Adelson PD, et al. Assessment of antioxidant reserves and oxidative stress in cerebrospinal fluid after severe traumatic brain injury in infants and children. Pediatr Res. (2002) 51:571-8. doi: 10.1203/00006450-200205000-00005

88. Mandrioli J, Del Rio D, Zini A, Nichelli P, Merelli E, Beltrami D, et al. Total antioxidant capacity of cerebrospinal fluid is decreased in patients with motor neuron disease. Neurosci Lett. (2006) 401:2038. doi: 10.1016/j.neulet.2006.03.013
89. NHS Direct Wales. Cerebrovascular disease. (2016) Available online at: www.nhsdirect.wales.nhs.uk\%2FEncyclopaedia\%2Fc\%2Farticle \%2Fcerebrovasculardisease\%2F\&usg=AOvVaw26hf9MDx6pwDZANv4_ 16MD (accessed April 1, 2020).

90. Mehndiratta MM, Hughes RA, Agarwal P. Plasma exchange for chronic inflammatory demyelinating polyradiculoneuropathy. Cochrane Database Syst Rev. (2004) 2004:CD003906. doi: 10.1002/14651858.CD003906.pub2

91. Cortese I, Cornblath DR. Therapeutic plasma exchange in neurology 2012. J Clin Apher. (2013) 28:16-9. doi: 10.1002/jca.21266

92. D’Andrea MR. Evidence linking neuronal cell death to autoimmunity in alzheimer's disease. Brain Res. (2003) 982:1930. doi: 10.1016/S0006-8993(03)02881-6

93. Mruthinti S, Buccafusco JJ, Hill WD, Waller JL, Jackson TW, Zamrini EY, et al. Autoimmunity in alzheimer's disease: increased levels of circulating IgGs binding Abeta and rage peptides. Neurobiol Aging. (2004) 25:102332. doi: 10.1016/j.neurobiolaging.2003.11.001

94. Loeffler DA, Juneau PL, Nguyen HU, Najman D, Pomara N, LeWitt PA. Immunocytochemical detection of anti-hippocampal antibodies in alzheimer's disease and normal cerebrospinal fluid. Neurochem Res. (1997) 22:209-14. doi: 10.1023/A:1027323809229

95. Villeda SA, Plambeck KE, Middeldorp J, Castellano JM, Mosher KI, Luo J, et al. Young blood reverses age-related impairments in cognitive function and synaptic plasticity in mice. Nat Med. (2014) 20:65963. doi: $10.1038 / \mathrm{nm} .3569$

96. Edison Group. Grifol's Study a Significant Development, but Not for the Reasons Grifols Would Like to Believe. (2018). Available online at: https://www.edisongroup.com/edison-sparks/grifols-study-a-significantdevelopment-but-not-for-the-reasons-grifols-would-like-to-believe/ (accessed September 2, 2019).

97. Boada M, López O, Núñez L, Szczepiorkowski ZM, Torres M, Grifols C, et al. Plasma exchange for alzheimer's disease management by albumin replacement (AMBAR) trial: study design and progress. Alzheimers Dement. (2019) 5:61-9. doi: 10.1016/j.trci.2019.01.001

98. Dodel R, Rominger A, Bartenstein P, Barkhof F, Blennow K, Förster $S$, et al. Intravenous immunoglobulin for treatment of mild-to-moderate alzheimer's disease: a phase 2, randomised, doubleblind, placebo-controlled, dose-finding trial. Lancet Neurol. (2013) 12:233-43. doi: 10.1016/S1474-4422(13)70014-0

99. Relkin NR, Thomas RG, Rissman RA, Brewer JB, Rafii MS, van Dyck CH, et al. A phase 3 trial of IV immunoglobulin for alzheimer disease. Neurology. (2017) 88:1768-75. doi: 10.1212/WNL.0000000000003904

100. Bayry J, Kazatchkine MD, Kaveri SV. Shortage of human intravenous immunoglobulin-reasons and possible solutions. Nat Clin Pract Neurol. (2007) 3:120-1. doi: 10.1038/ncpneuro0429

101. Dalakas MC. High-dose intravenous immunoglobulin and serum viscosity: risk of precipitating thromboembolic events. Neurology. (1994) 44:2236. doi: $10.1212 / \mathrm{WNL} .44 .2 .223$

102. Brannagan TH 3rd. Intravenous gammaglobulin (IVIg) for treatment of CIDP and related immune-mediated neuropathies. Neurology. (2002) 59:S33-40. doi: 10.1212/WNL.59.12_suppl_6.S33

103. O'Brien A. Con: the unclear benefit of albumin. Liver Transpl. (2019) 25:135-9. doi: 10.1002/lt.25384

104. Bosse D, Praus M, Kiessling P, Nyman L, Andresen C, Waters J, et al. Phase I comparability of recombinant human albumin and human serum albumin. J Clin Pharmacol. (2005) 45:57-67. doi: 10.1177/00912700042 69646

Disclaimer: The author has no connection to Grifols.

Conflict of Interest: The author declares that the research was conducted in the absence of any commercial or financial relationships that could be construed as a potential conflict of interest.

Copyright $\odot 2020$ Loeffler. This is an open-access article distributed under the terms of the Creative Commons Attribution License (CC BY). The use, distribution or reproduction in other forums is permitted, provided the original author(s) and the copyright owner(s) are credited and that the original publication in this journal is cited, in accordance with accepted academic practice. No use, distribution or reproduction is permitted which does not comply with these terms. 